This PDF is a selection from a published volume from the National Bureau of Economic Research

Volume Title: International Financial Issues in the Pacific Rim: Global Imbalances, Financial Liberalization, and Exchange Rate Policy (NBER-EASE Volume 17)

Volume Author/Editor: Takatoshi Ito and Andrew K. Rose, editors

Volume Publisher: The University of Chicago Press

Volume ISBN: 0-226-38682-1

Volume URL: http://www.nber.org/books/ito_08-1

Conference Dates: June 22-24, 2006

Publication Date: July 2008

Chapter Title: Growth and Returns in Emerging Markets

Chapter Author: Peter Blair Henry, Prakash Kannan

Chapter URL: http://www.nber.org/chapters/c6985

Chapter pages in book: (241 - 265) 


\section{Growth and Returns in Emerging Markets}

Peter Blair Henry and Prakash Kannan

\subsection{Introduction}

Conventional wisdom gives two rationales for investing in the stock markets of developing countries. The first states that the low correlation of developing-country stock returns with those of developed markets provides diversification opportunities that enable investors in developed countries to increase the expected return on their portfolio while reducing their risk. The second states that high rates of economic growth in emerging markets provide great absolute investment opportunities. Because the rate of economic growth in most developing countries is expected to exceed the rate of growth in the developed world for many years to come, the typical discussion presumes that long-run stock returns in emerging markets will also exceed those of developed markets (Malkiel and Mei, 1998; Mobius, 1994).

This chapter focuses on the empirical validity of the second rationale. To what extent do stock returns in developing countries track the real economy-GDP growth in particular-and is it true that stock returns in emerging markets are, on average, higher than in developed countries? The notion that stock returns in fast-growing countries will be higher than stock returns in slow-growing countries sounds almost too obvious to question, but the scatter diagram in figure 8.1 shows that there is no systematic long-run relationship between stock returns and economic growth

Peter Blair Henry is professor of economics and Gunn Faculty Scholar at the Stanford University Graduate School of Business, a faculty research associate of the National Bureau of Economic Research, and a nonresident senior fellow at the Brookings Institution. Prakash Kannan was a doctoral candidate at Stanford University when this paper was written. 


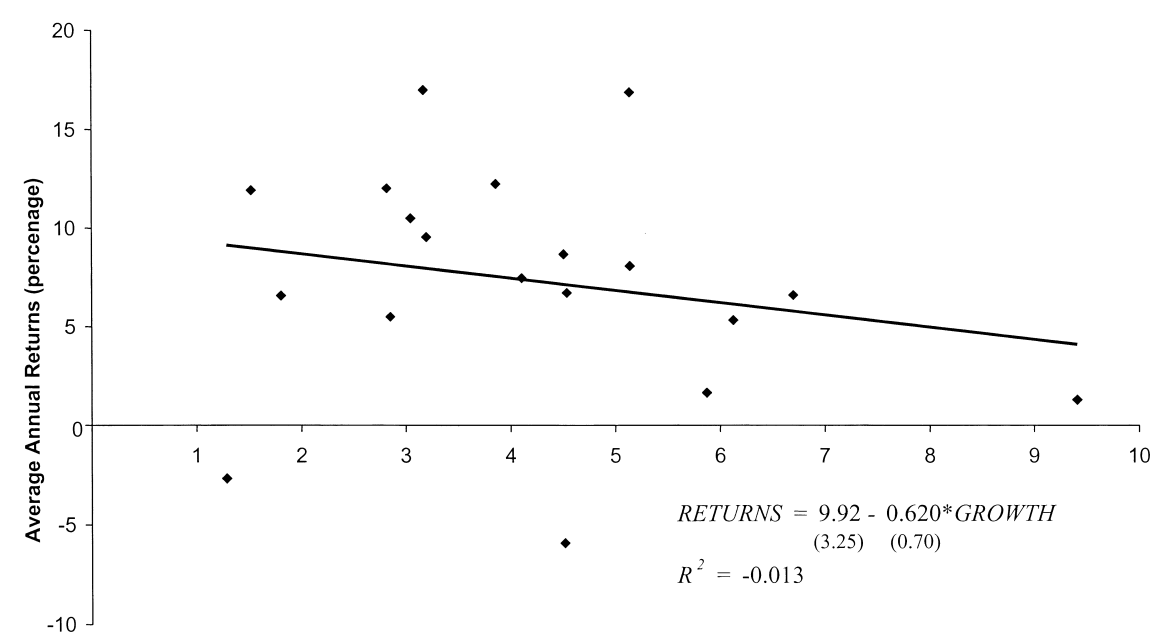

Average Annual Growth Rates (percentage)

Fig. 8.1 Stock returns and real GDP growth in emerging market economies are uncorrelated

in emerging economies over the past 30 years. ${ }^{1}$ Not only is the relationship between stock returns and economic growth statistically insignificant, the sign of the relationship actually goes the wrong way - it is negative instead of positive.

A simple example, using the Solow growth model, helps illustrate why higher economic growth does not always imply higher stock returns. Consider two emerging market economies (A and B) that are identical and therefore are growing at the same rate. A standard result of the Solow model is that an increase in the savings rate of country A will temporarily raise its rate of growth. It is also a standard result that an increase in the savings rate will reduce the rate of return to capital. The rate of return falls because the increase in the savings rate of country A drives up its rate of investment. Consequently capital becomes less scarce, and the marginal benefit from an additional unit falls. When diminishing returns has run its course, country A settles down to a new steady state, in which it has the same growth rate as country B, a higher level of GDP per capita, and a lower rate of return to capital.

This specific example illustrates a more general lesson. In order to understand whether a fast-growing emerging market economy will have higher stock returns than a slow-growing one, we must ask what accounts

1. Countries included in the scatter plot are Argentina, Brazil, Chile, China, Colombia, India, Indonesia, Jordan, Korea, Malaysia, Mexico, Nigeria, Pakistan, Philippines, South Africa, Thailand, Turkey, Venezuela, and Zimbabwe. 
for the difference in the two countries' growth rates of GDP. The stock market is the aggregate collection of financial claims on the real assets of an economy. Therefore, aggregate stock market returns should be tied to the rate of return to real assets in the long run. In turn, the rate of return to real assets depends on their productivity as determined by the interaction of capital, labor, technology, and institutions. For instance, in contrast to the previous savings rate example, the Solow Model predicts that high rates of growth caused by improvements in total factor productivity will raise the rate of return to capital.

These are not merely academic distinctions. Many scholars attribute the exceptionally high growth rates of Asian economies over the past three decades to the rapid rate of capital accumulation, made possible by the thriftiness of their populations rather than increases in the growth rate of total factor productivity (Krugman 1994; Young 1995). In the face of diminishing returns to capital, and an absence of increases in total factor productivity, growth rates of GDP per capita will slow to more pedestrian levels, and the rate of return to capital will fall.

However, a falling rate of return to capital in a given country tells you nothing about the level of its return to capital relative to rates of return elsewhere. This distinction is especially relevant when comparing emerging markets to more developed economies, such as the United States. For this comparison the convergence story within the neoclassical framework is more relevant. Emerging markets, which have lower capital-labor ratios than the United States, will tend to grow faster and have a higher rate of return to capital. Although East Asian economies have experienced significant capital deepening over the past few decades, as mentioned earlier, to the extent that they started from lower capital-labor ratios than the United States, their rates of return may still be higher.

A similar caveat about levels versus changes in rates of return applies to Latin America, a region where country after country in the past two decades have struggled with, and to varying degrees embraced, economic reforms. Reforms such as inflation stabilization, trade liberalization, and privatization all have potential to raise total factor productivity. If these reforms increase total factor productivity in the region, then they probably also drive up rates of return. But even if the rate of return to capital in Latin America is higher today than it was two decades ago, returns there could still be lower than in the United States.

While neoclassical theory provides the framework for the question of whether faster rates of economic growth in emerging markets translate into higher stock returns, our principal goal is to let the data speak for itself. In section 8.2 of this chapter we document that average realized stock returns in emerging markets over the last 30 years have not been significantly higher than realized stock returns in the United States. This finding is particularly striking in the case of fast-growing regions like Asia, which have 
average realized returns that are actually lower than returns in the United States.

There are legitimate objections to using realized stock returns to test the validity of the view that high growth and high stock returns go together. For instance, high rates of growth may be associated with high expected returns (as opposed to realized returns). To address this concern, section 8.3 constructs measures of expected returns using dividend-price ratios and earnings yields. Unlike the case of average realized rates of return, we find some evidence that average expected returns in emerging markets have been significantly higher than expected returns in the United States. We also document that average realized returns in emerging markets have generally been higher than average expected returns over the past 20 years.

To gain a better understanding of the forces that account for the higherthan-expected returns in emerging markets over the past two decades, section 8.4 presents short vignettes that focus on inflation stabilization and capital account liberalization episodes in Latin America and Asia. The central, if unsurprising, message that emerges from these vignettes is that stock markets respond positively to news about major economic reforms. Insofar as these reforms result in growth that was higher than expected, we find that markets respond positively and yield higher-than-expected returns as well. This significant positive correlation between unexpected growth and unexpected returns is shown to exist in both Latin America and in Asia.

Building on the discussion in section 8.4 , section 8.5 discusses a simple and consistent explanation for high growth with low returns in Asia and low growth with high returns in Latin America. High growth implies high returns only if the stock market has not already capitalized the growth into current prices. Entering the 1980s, the Asian Tigers had already experienced two decades of rapid output growth, and expectations for the future were great. In contrast, Latin America entered the 1980s well on its way to a debt crisis. Starting in 1986, and stretching over the next two decades, Latin American countries attempted to stabilize inflation, liberalize trade, and privatize state-owned enterprises. While these efforts were not entirely successful (and similar efforts also occurred in Asia), the very attempt at reform in Latin America was unexpected and thus probably not priced in. Hence, relative to the low expectations for the region at the start of the 1980s, Latin America achieved better outcomes than Asia over the next 20 years. This hypothesis is consistent with the results of the regressions carried out in section 8.4, where unexpected returns were shown to be positively correlated with unexpected growth.

\subsection{Data}

In order to compare rates of return in emerging economies with those in mature markets, we compute dollar-denominated, inflation-adjusted stock 
returns for a number of countries. All of the stock market data come from Standard and Poor's (S\&P) Emerging Markets Data Base (EMDB). We use the dividend-inclusive, total return index, denominated in U.S. dollars. We compute a real, inflation-adjusted index by deflating the total return index with the U.S. consumer price index. The consumer price index data come from the Bureau of Economic Analysis.

The EMDB provides the most complete and consistent source of stock returns across a wide range of developing countries. Nevertheless, the EMDB data are less than ideal. For some of the larger emerging markets in Latin America and Asia, we have thirty years of stock returns (1976 to 2005). For other countries, most notably those of Eastern Europe, data are only available from the early 1990s. For valuation ratios, the data limitations are even greater. Even in the countries with thirty years of stock price data, price earnings ratios are only available since 1986. By comparison, long-term studies of the U.S. stock market typically employ time series that span close to 100 years (Blanchard 1993; Fama and French 2002).

Stock returns over long periods of time provide a reasonable proxy for the rate of return to capital in an economy, but returns viewed over shorter horizons may not be as easy to interpret. Because of movement in the business cycle and the volatility of returns, our time series may not be long enough to distinguish meaningful information from noise in the data. Nevertheless, a dataset with limitations is better than no dataset at all, so we proceed to calculate long-run returns with the data we have.

Table 8.1 summarizes the average annual realized real return and standard deviation for a selection of twenty emerging market economies during the period 1976 to 2005 . For each country in the sample we calculate annual real returns, using continuously compounded growth rates - the natural log of the inflation-adjusted, dividend-inclusive value of the index at the end of the year minus the natural log of the same variable at the beginning of the year. The average annual real return for a country is the simple average of its continuously compounded annual return. In turn, the average annual return for a particular region is the simple average of the average annual real return of all countries in that region. ${ }^{2}$

Panel A of table 8.1 shows that average annual stock returns in emerging markets over the past thirty years have been 7.78 percent per year, while the average return on the U.S. market over the same period was 7.69 percent. The two sets of returns are statistically indistinguishable. Hence, at least from an ex-post point of view, stock returns in emerging markets are no higher than stock returns in the United States. Individual country data in table 8.2 show that the averages are representative of the group as a whole.

The use of country weights to compute regional averages, as opposed to

2. Note that these numbers differ slightly from the regional averages computed by EMDB due to the range of countries included and the use of a simple average here as opposed to a weighted average used in the EMDB computations. 
Table 8.1

Realized returns in emerging markets are not significantly higher than realized returns in the United States ${ }^{\mathrm{a}}$

\begin{tabular}{|c|c|c|c|c|}
\hline & $\begin{array}{l}\text { Average } \\
\text { Return }\end{array}$ & $\begin{array}{l}\text { Standard } \\
\text { Deviation }\end{array}$ & $\begin{array}{l}\text { Sharpe } \\
\text { Ratio }\end{array}$ & $\begin{array}{c}\text { Correlation } \\
\text { with U.S. }\end{array}$ \\
\hline \multicolumn{5}{|c|}{ A: Continuously Compounded Returns } \\
\hline Composite $^{\mathrm{b}}$ & 7.78 & 23.98 & 0.22 & 0.21 \\
\hline Latin America ${ }^{\mathrm{c}}$ & 10.86 & 35.24 & 0.24 & 0.31 \\
\hline $\mathrm{Asia}^{\mathrm{d}}$ & 6.62 & 30.05 & 0.14 & 0.09 \\
\hline U.S. & 7.69 & 14.57 & 0.36 & 1.00 \\
\hline \multicolumn{5}{|c|}{ B: Arithmetic Returns } \\
\hline Emerging Market Composite ${ }^{\mathrm{b}}$ & 23.57 & 30.45 & 0.70 & 0.22 \\
\hline Latin America $^{c}$ & 31.01 & 49.40 & 0.58 & 0.25 \\
\hline Asia $^{\mathrm{d}}$ & 16.35 & 33.83 & 0.41 & 0.12 \\
\hline U.S. & 9.54 & 15.81 & 0.45 & 1.00 \\
\hline
\end{tabular}

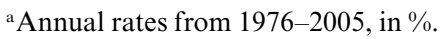

${ }^{\mathrm{b} C}$ Composite returns are the average returns of the following economies: Argentina, Brazil, Chile, China, Colombia, India, Indonesia, Jordan, Korea, Malaysia, Mexico, Nigeria, Pakistan, Philippines, South Africa, Taiwan, Thailand, Turkey, Venezuela, and Zimbabwe.

${ }^{\circ}$ Latin America returns are the average returns of Argentina, Brazil, Chile, Colombia, Mexico and Venezuela.

${ }^{\mathrm{d}}$ Asia returns are the average returns of China, India, Indonesia, Korea, Malaysia, Philippines, Taiwan and Thailand.

simple averages (as used in table 8.1) does not alter our findings. The EMDB dataset contains weighted averages of regional returns where the weighting is done by market capitalization. The average annual return for the EMDB composite during the period 1985-2005 (data for this series are only available from 1985 onward) is 8.30 percent compared to an average return of 9.05 percent in the United States over the same period. Thus, even when weighted, we find that average annual stock returns for emerging market economies are not higher than returns in the United States. The EMDB regional averages, which are weighted, also support our findings from table 8.1. The average annual return for the Latin American aggregate is 14.0 for the period 1985-2005, while the comparable figure for the Asian aggregate is 5.06 percent.

In contrast to the numbers in Panel A, studies that compute stock returns arithmetically find that emerging markets have higher annual returns than the United States. For instance, Harvey (1995) reports a 20.36 percent dollar return on the emerging market composite index as compared to a 13.63 percent return on the United States market. ${ }^{3}$ Arithmetic returns overstate the financial performance of emerging markets. Figure 8.2 shows why. It plots the evolution of the inflation-adjusted value of a dollar invested in various stock markets starting in 1975 (with full reinvestment of

3. Panel B of table 8.1 shows that this result obtains in an updated sample. 


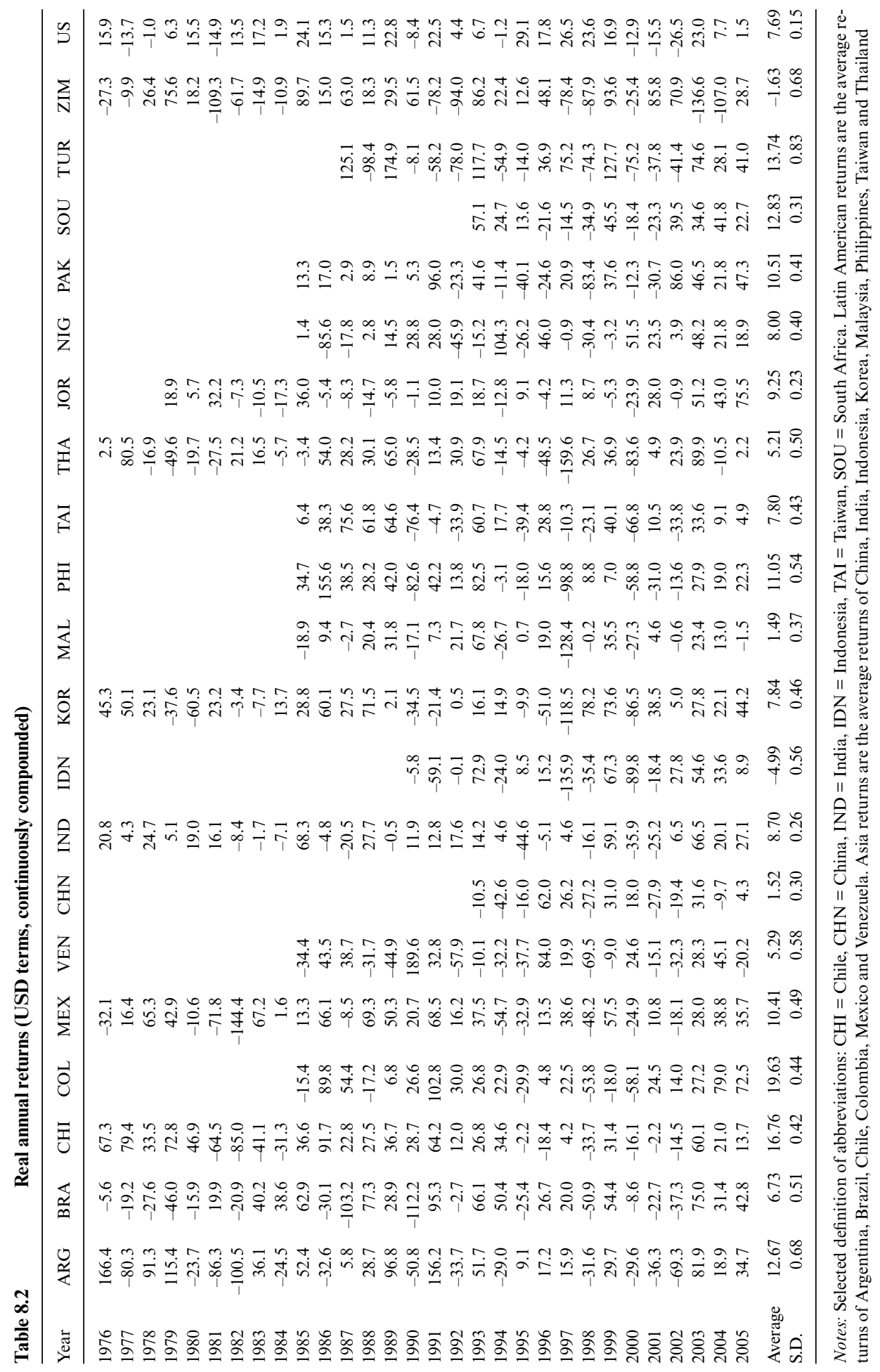




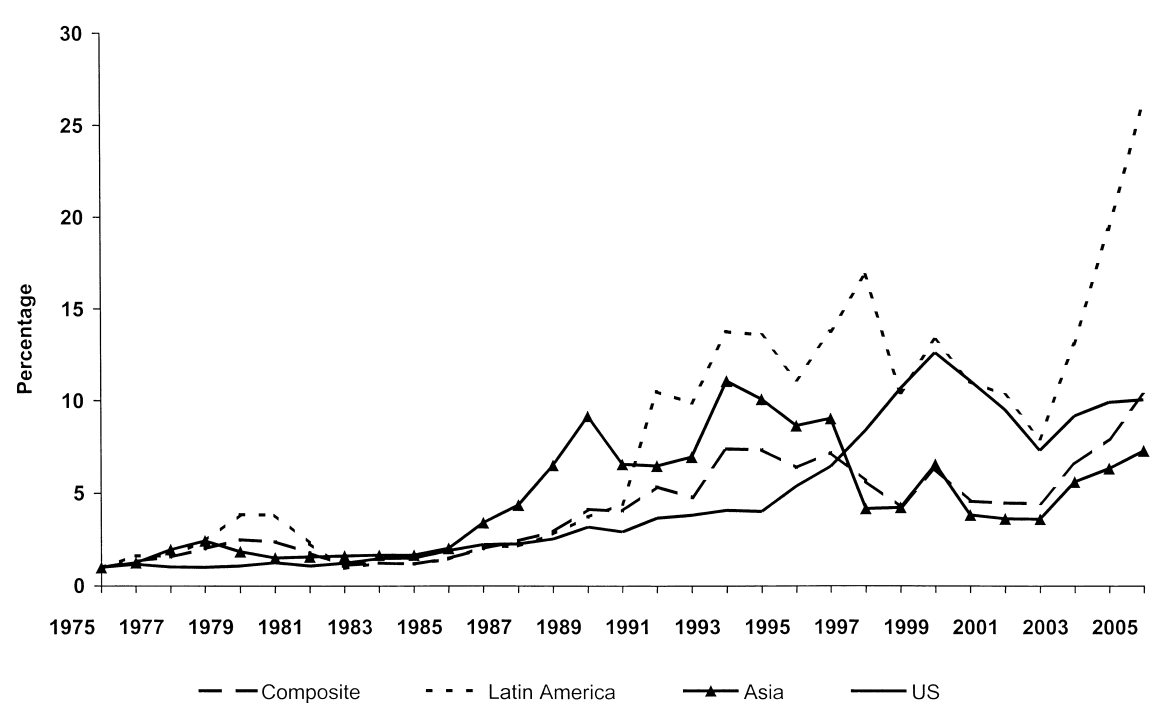

Fig. 8.2 The inflation-adjusted value of a dollar invested in $\mathbf{1 9 7 5}$

dividends). The arithmetic average of year-by-year arithmetic returns in the period from 1975 to 1987 is 13.9 percent for Latin America versus 7.8 percent for the United States. This gives the misleading impression that the value of the Latin American investment at the end of the twelve-year period is greater than the value of the U.S. investment when, in fact, the opposite is true. A dollar invested in Latin America in 1975 was worth $\$ 2.15$ in 1987. A dollar invested in the United States over the same period grew to a value of $\$ 2.26$.

While continuously compounded mean returns are about the same in emerging markets as in the United States, the emerging market composite index displays substantially higher volatility. Column 2 of table 8.1 shows that the standard deviation of emerging market returns is roughly one and a half times that of the United States. Accordingly, the Sharpe Ratios in column 3 indicate that the higher risk associated with emerging markets has not resulted in higher returns. In spite of the poor absolute performance indicated by their Sharpe ratios, it is well known that emerging markets have the potential to improve the risk-return profile of a balanced portfolio because of their low correlation with developed countries (Harvey 1995). Column 4 of table 8.1 shows that emerging market returns continue to exhibit relatively low correlation with U.S. returns.

Focusing on returns at the broad level of emerging markets masks significant heterogeneity across regions. Compared to returns in the United States, Latin American stocks produced higher average returns over the same period. The average-annual return on Latin American stocks was 
10.86 percent, compared to the 7.69 percent return on U.S. stocks (although this difference is not statistically significant). The higher volatility of Latin American stocks, however, means that they also have low Sharpe ratios relative to the United States. Meanwhile, stocks in Asia have performed worse on both counts - they have had lower than average returns than stocks in the United States and higher volatility. Within the group, stocks in Indonesia, for example, produced an average annual real rate of return of negative 5 percent over this 30 -year period. Even with the exclusion of Indonesia, average stock returns in Asia are only 6.9 percent over the period.

The relatively low real rate of return on Asian stocks weighs heavily against the view that high growth generates high returns. While Asian countries such as China, India, and Korea experienced high rates of growth relative to the United States and Latin America, the average annual realized return for Asia is the lowest among all three regions. A natural question to ask is whether this observation would still hold if we eliminated the influence of the 1997 Asian Crisis in our calculations. Three points are in order here.

First, even excluding the Asian Crisis, average real returns in Asia remain lower than in Latin America. Real continuously compounded returns in Asia from 1975 to 1996 were 10 percent; in Latin America they were 12.48. If instead of eliminating all of the data after 1996, we calculate returns for Asia using all years except 1997, average returns for Asia are 9.53 percent; returns calculated in the same way for Latin America are 10.54 percent.

Second, given the timing of the 1997 Asian Crisis, there is no theoretical justification for excluding data during that time period from our calculations. The returns series includes an ample number of years following the crisis to balance any undue influence that would occur if the series ended on a down year in the business cycle.

Third, and related to the second point, we are skeptical of throwing away data. The same instinct that suggests you should calculate Asian returns without including the 1997 data would also suggest that you throw away data on stock returns in Latin America during the debt crisis (1982 to 1989). For that matter, why not exclude data from the Mexican and Argentine crisis periods? Indeed, given the volatility of returns in emerging markets, we would soon be left with little of an already-limited sample of data.

The possibility of survivorship bias should be mentioned. A sample that disproportionately represents firms or markets that have survived over time will produce average rates of return that are higher than a sample that includes failed firms or markets (see Goetzmann and Jorion 1999). For our comparison of emerging market returns relative to those of the United States, the possibility of survivorship bias actually strengthens our conclu- 
sion that emerging market returns are not significantly higher than returns in the United States, if we believe that the failure rate of firms in emerging markets is higher than in the United States. The effect of survivorship bias on the comparison between returns in Asia and Latin America, however, is less clear. It could be argued that the higher degree of turbulence in Latin American countries accounts for the higher rate of return relative to Asian economies. However, without more detailed firm-level data in these economies, we cannot know the extent of the bias, if it exists.

On the whole, the data in table 8.1 demonstrate that historical stock returns provide little support to the view that higher growth rates and higher risk in emerging markets produce commensurately higher rates of return. The evidence in table 8.1, however, requires a cautious interpretation. The data on realized returns span a thirty-year period during which a number of crises and reforms occurred in the developing world. As such, it may be the case that the average realized rates of return computed in table 8.1 differ significantly from the average expected returns in these economies over the period. We turn our attention to this distinction in the next section.

\subsection{Expected Returns Versus Realized Returns}

In order to compute expected rates of return we begin by using the constant dividend-growth model, or as it is more popularly known, the Gordon Model (Gordon 1962). The Gordon model states that the price of a stock should be equal to the dividend payment divided by the difference between the required rate of return for the stock and the expected long-term growth rate of dividends:

$$
P=\frac{D}{\rho-g^{e}},
$$

where $D$ is the dividend, $P$ is the stock price, $\rho$ is the required rate of return, and $g^{e}$ is the expected growth rate of the dividend stream. Rearranging equation (1) with $\rho$ on the left-hand-side gives an expression that states that the required rate of return on a stock is the sum of its current dividendprice ratio and the expected growth rate of future dividends:

$$
\rho=\frac{D}{P}+g^{e}
$$

In order to use equation (2) to compute expected returns, we need a measure of expected future growth rates that we can add to the dividend-price ratio data we obtain from the EMDB. Because capital's share in national output within a given country does not fluctuate much over time (although it may vary significantly across countries), it is reasonable to assume that in the long-run, earnings grow at the same rate as gross domestic product (GDP). The issue then becomes how to construct a measure of the ex- 
pected future growth rate of GDP. Here we turn to the International Monetary Fund (IMF) publication, the World Economic Outlook (WEO).

The $W E O$ provides annual analysis and forecasts for the world economy. Every year, the $W E O$ produces three sets of numbers for a variety of countries and regions: (a) A forecast of GDP growth for the current year (year [0]); (b) a forecast of growth for the following year (year [+1]); and (c) a forecast of the average expected growth rate for the next four years (years $[+2$ to +5$]) .{ }^{4}$ Since the Gordon model assumes a constant expected future growth rate, the proper empirical analogue for $g^{e}$ is a long-term forecast, not the growth forecast for any single year. In order to capture the spirit of the model, we calculate $g^{e}$ as the geometric average of the three numbers provided in the $W E O$ forecast-in essence, the average expected growth rate over the next five years.

A simple example may help. Suppose that we want to calculate the expected return for Latin America in 1995. The first step is to produce, from the perspective of a market investor in 1995, a forecast of the expected future dividend growth rate. To do so, we open the 1995 issue of the WEO and find that the forecast for Latin American growth (as approximated by the Western Hemisphere region) in 1995 was 2.1 percent, the forecast for 1996 was 4.0 percent, and the forecast for 1997 through 2000 was an annual growth rate of 5.3 percent. Given these three numbers, our estimate of the expected future dividend growth rate for Latin America in 1995 is 4.5 percent.

Table 8.3 presents our calculations of average expected returns from 1985 to 2005 . The time period in table 8.3 is shorter than that for table 8.1, because data on the dividend price ratio for the individual economies is only available since 1985 . Table 8.3 also presents data on the values of the underlying variables that comprise our calculation of expected returns. Column 1 gives the dividend-price ratio, column 2 the expected future growth rate of dividends. Column 3, which presents the sum of the first two columns, shows that over the period 1985-2005, average expected returns for the Composite Emerging Market Index, Latin America, and Asia were all higher than average expected returns in the United States.

To test whether these differences are statistically significant we pooled the expected-returns data and then ran a regression of annual expected returns on a constant and regional dummies (with the United States as a base). The coefficients on all of the regional dummies were significant. In other words, from 1985 to 2005, expected returns in Asia, Latin America, and emerging markets as a whole were significantly higher than expected

4. Strictly speaking, the IMF only began to consistently publish forecasts for developing economies along the lines mentioned in the main text from their 1995 issue of the WEO. For the earlier years, we used the regional growth forecasts for "net debtor developing countries." The composition of countries between the two groups is not significantly different. Where possible, we use the September/October issue of the WEO for that year. 


\begin{tabular}{|c|c|c|c|c|c|c|}
\hline & $\mathrm{D} / \mathrm{P}$ & $\mathrm{g}^{\mathrm{e}}$ & $\begin{array}{c}\text { Expected } \\
\text { return: } \\
\mathrm{DP}+\mathrm{g}^{\mathrm{e}}\end{array}$ & $\begin{array}{c}\text { Expected } \\
\text { return: } \\
\mathrm{E} / \mathrm{P}^{\mathrm{a}}\end{array}$ & $\begin{array}{l}\text { Realized } \\
\text { return }\end{array}$ & $\begin{array}{l}\text { Realized } \\
\text { Growth }\end{array}$ \\
\hline Emerging market composite & 3.17 & 5.24 & 8.41 & 6.27 & 10.32 & 5.48 \\
\hline Latin America & 3.85 & 3.89 & 7.74 & 9.69 & 14.68 & 2.94 \\
\hline Asia & 1.86 & 6.47 & 8.33 & 4.17 & 7.01 & 7.41 \\
\hline U.S. & 2.48 & 2.83 & 5.31 & 4.96 & 9.05 & 2.98 \\
\hline
\end{tabular}

${ }^{\text {aE} E a r n i n g s-p r i c e ~ d a t a ~ o n l y ~ b e g i n ~ f r o m ~} 1986$.

returns in the United States. In contrast, the average realized returns for Asia, Latin America, and the composite emerging market index in table 8.1 were not significantly different from the realized returns for the United States.

It is also instructive to compare expected returns with realized returns for a given region. Column 5 in table 8.3 shows the average realized annual return for each region over the same time period. For every emerging market region except Asia, we find that average realized returns exceeded average expected returns over the past two decades. Average realized returns for the United States also exceeded average expected returns over the period. This result is consistent with Fama and French (2002). Using an equation analogous to equation (2), they find that average realized returns for the United States over the period 1951-2000 were much higher than the average expected return.

\subsubsection{Expected Returns Using the Earnings Yield}

Using the dividend-price ratio to calculate expected returns has its disadvantages. As we can see from equation (2), the expected rate of return depends on dividend policy. For instance, suppose that earnings rise, but firms decide not to increase their cash payouts to shareholders. Because earnings rise, so will the firm's stock price. But without any change in dividend policy, the dividend price ratio will fall, thereby reducing the level of expected returns implied by equation (2). If the increase in earnings were permanent, one would eventually expect an increase in payouts. But given the persistence of dividend policy, the shortness of our earnings-yield series, and the increasing tendency of firms to distribute payouts in forms other than dividends, the change in earnings could have a nontrivial impact on our calculation of expected returns. This is an unattractive feature, because dividend policy is independent of real operations, like investment decisions, that ultimately drive fundamental firm value (Modigliani and Miller 1958).

Since earnings, not dividends, drive long-run value, the earnings yield 
E/P provides a more robust measure of aggregate expected returns. ${ }^{5}$ It is true that for a given firm, the earnings yield may not accurately measure its expected return. The firm's earnings yield accurately measures the firm's expected returns only when the marginal product of capital equals the cost of capital. When the firm's marginal product of capital exceeds its cost of capital, then the earnings yield will understate the firm's expected rate of return, and vice versa. While it is reasonable to expect that any firm may earn positive or negative economic profits for some period of time, there is no reason to think the same is true for the economy as a whole.

Column 4 of table 8.3 presents average earnings yields for the Composite Emerging Market Index, for Asia, Latin America, and the United States. The basic message about expected returns in emerging markets versus the United States does not change when we use earnings yields. With the exception of Asia, the average earnings yield for all emerging market regions between 1986 and 2005 was higher than in the United States. The average level of expected returns was 9.69 for Latin America, 6.27 for all emerging markets, and 4.17 for Asia. The average level of earnings yields for the United States during this period was 4.96. It is also worth noting that for any given region, average realized returns always exceed average earnings yields. However, given the shortness of the time series and the volatility of realized returns, this result is not statistically significant.

Two main points emerge from table 8.3. First, unlike the realized rates of return computed in table 8.1, expected rates of return in emerging markets are significantly different from expected returns in the United States. Using either the earnings yield or the dividend-price-ratio-based measure, average expected returns over the period 1985-2005 were higher in Latin America and Asia than in the United States. Second, almost without exception, average realized returns in emerging economies over the past two decades have been higher than expected. The question, then, is: what forces drive average realized returns in emerging market economies away from average expected returns? This is the topic to which we now turn.

\subsection{Regional Vignettes}

There are many potential explanations for the difference between realized and expected returns in emerging markets, but the economic reforms of the past two decades surely play a very prominent role. The most important issue in Latin America is the vanquishing of high inflation. Figure 8.3 shows that inflation began a precipitous decline in 1991 and continued

5. Mankiw (2005) also argues for the use of the earnings-price ratio over the dividend price ratio. 


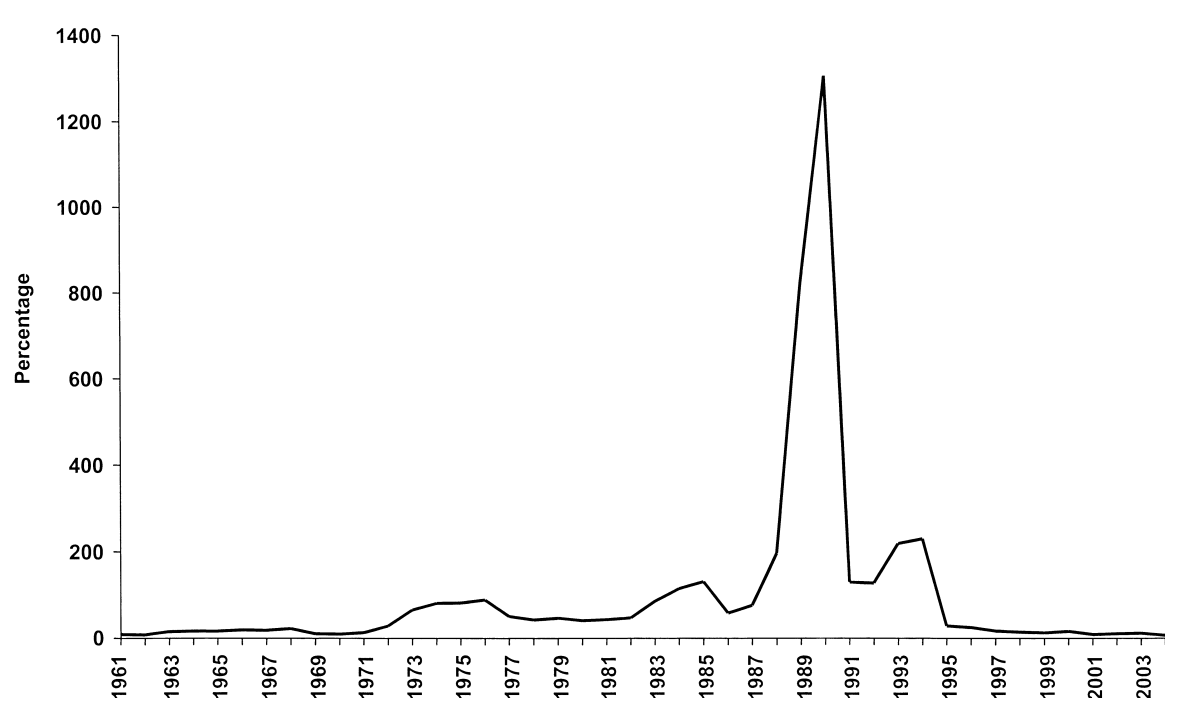

Fig. 8.3 Latin America, average inflation rate (annual percentage change in CPI)

falling through the 1990s. Latin America's disinflation is even more impressive when viewed in event time (figure 8.4).

Year 0 on the $x$-axis of figure 8.4 corresponds to the year in which each of the four successful disinflation episodes in the sample took place: the Mexican Pacto in 1987, Argentina's Convertibility Plan in 1991, the Real Plan in Brazil in 1994, and Chile's more garden-variety stabilization in 1989 under its last IMF program to date. Of course, the reduction in inflation is only part of the story. Immediately preceding the drop in inflation in 1991, Mexico became the first country to receive debt relief under the Brady Plan (1989), Brazil substantially liberalized trade (1990), and Venezuela opened its stock market to foreign investment (1990).

To examine whether the good news of economic reforms in Latin America drove up realized returns relative to expected returns, define the variable, UNEXPECTED RETURNS, as the realized return on the stock market in a given year, minus the expected return on the stock market (as measured in table 8.3) in the same year. For example, in 1991 the unexpected return is 77.8 percent using the earnings-based measure of expected returns and 81.9 percent using the dividend-based measure. The unexpected returns variable captures the extent to which new information drives a wedge between expected returns and realized returns. For instance, news about changes in policy may lead to unexpected capital gains because changes in policy lead to unexpected changes in growth. Indeed, in 1991 realized growth in Latin America exceeded expected growth by almost a full percentage point (3.9 versus 3.16$)$. 


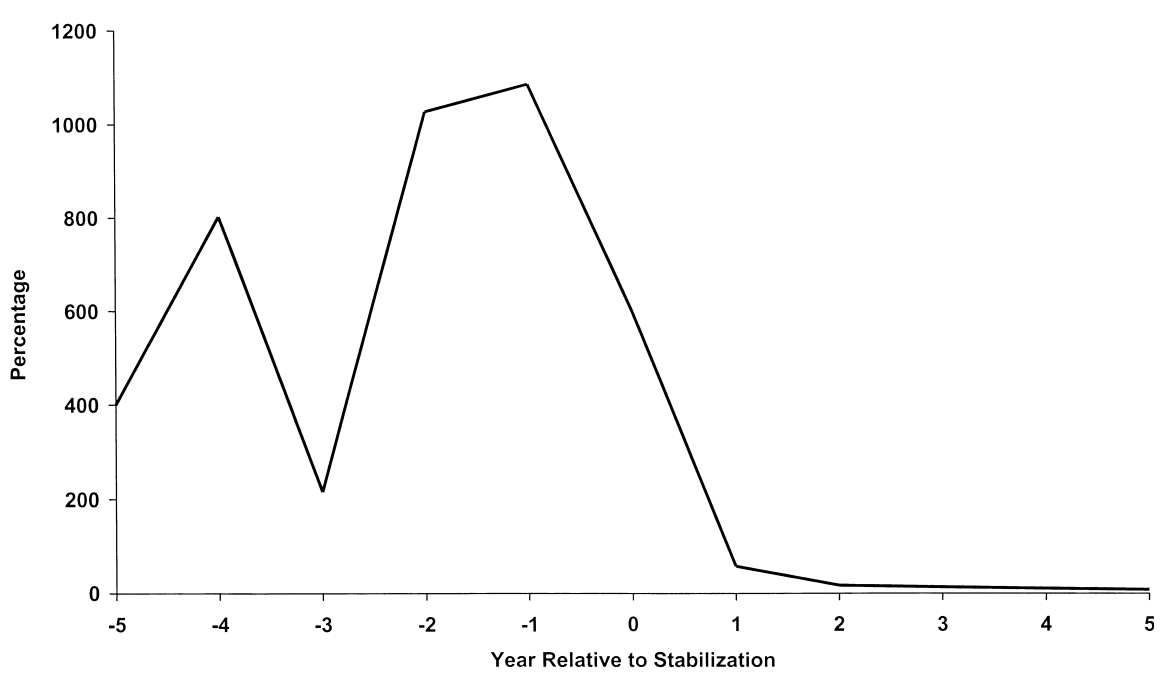

Fig. 8.4 Inflation rates in Latin American countries around stabilization episodes

The relation between unexpected returns and unexpected growth also works in the other direction. In 1994, the $W E O$ forecasted that GDP in Latin America would grow by 3.3 percent in 1995. In December of 1994, Mexico devalued the peso, plunging the country into a full-fledged financial crisis. The peso crisis sent shock waves throughout Latin America. In order to maintain its fixed exchange rate, Argentina raised interest rates, financial tightening ensued throughout the region, and economic activity slowed accordingly. As a consequence, Latin America grew by only 1.8 percent in 1995 . With realized growth falling 1.5 percentage points ( 1.8 minus 3.3) short of expectations for that year, Latin American stock returns also came in lower than expected. The unexpected return variable in 1995 was negative 28.7 percent using the earnings measure of expected returns and negative 27.3 percent using the dividend measure.

More generally, a significant correlation exists between unexpected returns and unexpected growth in Latin America:

(3) UNEXPECTED RETURN $=15.2+8.7 \cdot U N E X P E C T E D$ GROWTH

Adjusted $R$-Squared $=0.184, N=21$ (standard errors in parentheses).

\subsubsection{East Asia}

The emerging economies of East Asia did not have the serious inflation problems of Latin America. But like Latin America, the East Asian economies also began opening their stock markets to foreign investment in the 
1980s. Significant liberalizations of restrictions of foreign ownership of domestic stocks took place in the Philippines in 1986, Taiwan in 1986, India in 1986, Malaysia in 1987, South Korea in 1987, and Thailand in 1988. Because emerging economies are capital-scarce relative to the developed world, opening the stock market to foreign investment has the potential to reduce a country's cost of capital. ${ }^{6}$ Figure 8.5 suggests that the cost of capital may indeed fall when countries liberalize. The graph displays the profile of the average dividend yield across each of the five Asian economies that liberalized between 1986 and 1988. The average dividend yield falls by 231 basis points as a result of liberalization. The average growth forecast rises by fifty-one basis points. From equation (2), the approximate fall in the cost of capital is equal to the difference-180 basis points.

When a country experiences an unexpected fall in its cost of capital, stock prices should increase, thereby generating a positive unexpected return. Consistent with the notion that liberalization generates positive unexpected returns, during the three-year period from 1986 to 1988, the average wedge between realized returns and expected returns in the five Asian economies was 28.1 percent, according to the earnings-based measure of expected returns, and 25.9 percent according to the dividend-based measure.

A lower cost of capital also has real implications - namely, more investment, and faster economic growth in the short term (Bekaert, Harvey, and Lundblad 2005; Henry 2000b; Henry 2003). Accordingly, over the threeyear liberalization period from 1986 to 1988, actual GDP growth in emerging Asia exceeds expected growth by an average of 1.9 percentage points per year ( 7.8 versus 5.9 percent). Again, as in Latin America, a more general correlation holds between unexpected returns and unexpected growth:

\section{UNEXPECTED RETURN $=-13.9+13.4 \cdot$ UNEXPECTED GROWTH}

Adjusted $R$-Squared $=0.21, N=21$ (standard errors in parentheses)

The negative intercept term in equation (4) reflects the extreme influence of the Asian crisis on estimates of unexpected returns in a regression with only 21 data points. Nevertheless, we learn a lot from the outlier, which is the Asian crisis of 1997. In 1997, the actual growth rate of GDP in Indonesia, Korea, Malaysia, and Thailand was four percentage points below expected growth, and realized returns were 90.1 percentage points less than expected returns.

Pooling all of the available data, we also estimate the average relationship between unexpected returns and unexpected growth across Latin America, Asia, and developed markets:

6. See Stulz (1999), Bekaert and Harvey (2000), and Henry (2000a) for detailed discussions about the impact of liberalization on the cost of capital. 


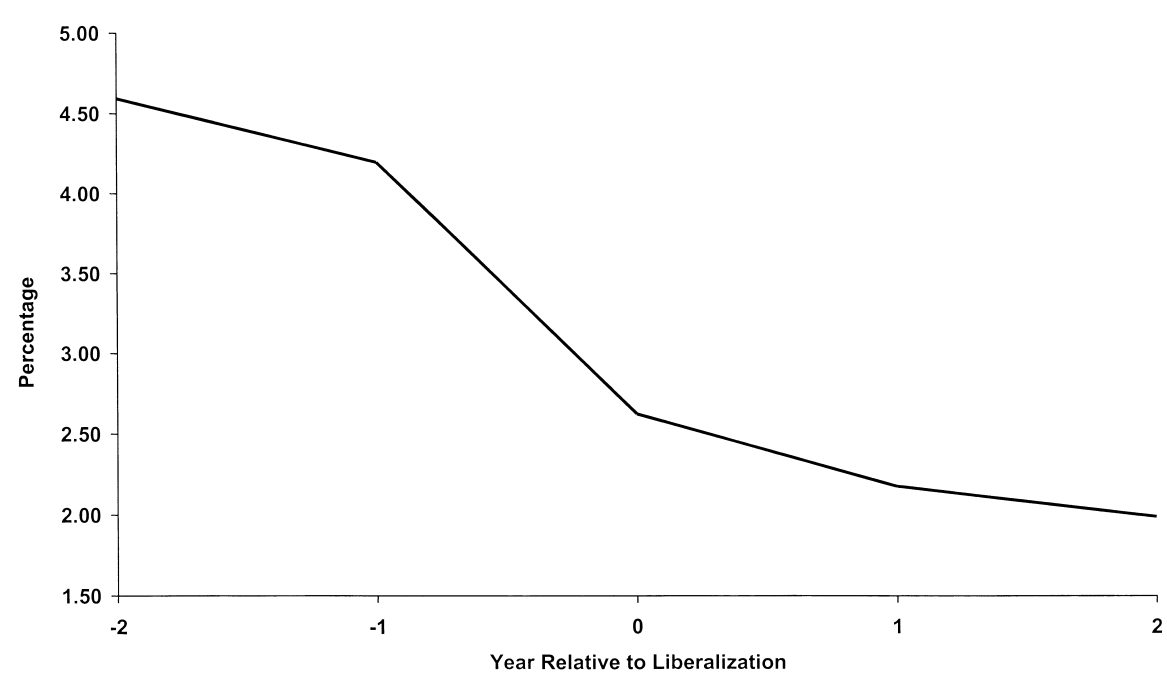

Fig. 8.5 Dividend-yields in Asian economies around capital account liberalization episodes

(5) UNEXPECTED RETURN $=2.9+5.9 \cdot$ UNEXPECTED GROWTH

Adjusted $R$-Squared $=0.09, N=63$ (standard errors in parentheses)

The general message here is that unexpected growth significantly predicts unexpected returns. Not surprisingly, from 2002 to 2005, GDP growth in emerging markets has been stronger than expected and realized returns have exceeded expected returns.

\subsection{Discussion}

From 1985 to 2005, the average realized return on Latin American stocks was 14.68 percent per year (table 8.3). Realized returns consist of dividend yields plus capital gains. Since the average dividend yield for Latin America over the period was 3.85 percent per year, average annual capital gains come to 10.83 percent per year. The corresponding figures for Asia are realized returns of 7.01 percent per year, a dividend yield of 1.86 per year, and a capital gain of 5.15 percent per year. In other words, over the past twenty years, capital gains in Latin America exceeded those in Asia by a factor of two. Yet over the same period of time, average annual inflation in Asia was much lower than in Latin America-6.4 percent versus 167 percent — and growth was much higher-7.41 percent per year as compared to 2.91 percent per year. What can explain these facts?

Unexpected changes in the economic environment cause unexpected 
capital gains (or losses). Relative to initial expectations, Latin America has had better outcomes than Asia over the past two decades. Taken at face value, this assertion sounds a bit far-fetched, but it becomes less so upon deeper reflection. In the 1980s the Asian Tigers were well on their way to achieving the status of newly industrializing countries. They had already experienced two decades of rapid output growth and their expectations for the future were great. Accordingly, price-earnings ratios in Asia were high in 1986 - 18.29, to be exact. In contrast, the early 1980s saw Latin America fall headlong into a debt crisis. Inflation was high, growth was low, and perhaps most importantly, growth rates in Latin America had begun to diverge substantially from those in Asia (see figure 8.6). The price-earnings ratio of 3.53 for Latin American stocks in 1986 reflected a dismal outlook for the region.

In short, a simple and consistent explanation for high growth with low returns in Asia and low growth with high returns in Latin America goes as follows: High growth implies high returns only if the stock market has not already capitalized the growth into current prices. To the extent that corporate earnings grow, so will stock prices. When there is good news about the future that is not captured in current earnings, prices will increase relative to earnings, and shareholders will experience unexpected capital gains.

In 1986, price-earnings ratios in Latin America and Asia were substantially different. Stock markets in Asia had already priced-in high expected

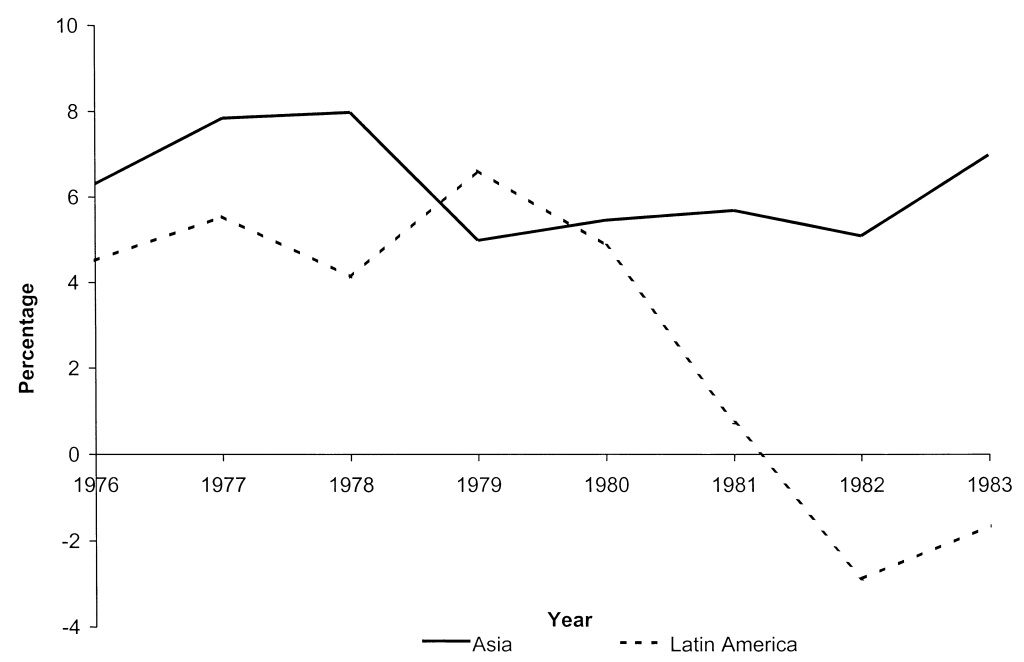

Fig. 8.6 GDP growth in Asia and Latin America, 1976-1983 (converted at market exchange rate)

Source: World Development Indicators, The World Bank 
future growth, but by reducing the cost of capital, opening the stock market to foreign investors generated some unexpected capital gains in the mid- to late-1980s (figure 8.5). However, in addition to opening to foreign capital flows, Latin American countries also attempted to stabilize inflation, liberalize trade, and privatize state-owned enterprises. While these efforts were not uniformly successful (and some also occurred in Asia), the very attempt to move the region in this direction was a shock, given low expectations at the time. Hence, the scope of reforms and the magnitude of unexpected capital gains in Asia were modest in comparison with what was yet to occur in Latin America.

\section{References}

Bekaert, G., and C. Harvey. 2000. Foreign speculators and emerging equity markets. Journal of Finance 55:565-613.

Bekaert, G., C. Harvey, and C. Lundblad. 2005. Does financial liberalization spur growth? Journal of Financial Economics 77:3-56.

Blanchard, O. 1993. Movements in the equity premium. Brookings Papers on Economic Activity 2:75-138.

Fama, E., and K. French. 2002. The equity premium. Journal of Finance 57 (1): 637-59.

Gordon, M. 1962. The investment, financing, and valuation of the corporation. Ontario, Canada: Irwin.

Goetzmann, W. N., and P. Jorion. 1999. Re-emerging markets. Journal of Financial and Quantitative Analysis 34 (1): 1-32.

Harvey, C. 1995. Predictable risk and return in emerging markets. Review of Financial Studies 8 (3): 773-816.

Henry, P. 2000a. Do stock market liberalizations cause investment booms? Journal of Financial Economics 58 (1-2): 301-34.

.2000b. Stock market liberalization, economic reform and emerging market equity prices. Journal of Finance 55 (2): 529-64.

. 2003. Capital account liberalization, the cost of capital and economic growth. American Economic Review 93 (2): 91-96.

International Monetary Fund. 1984-2005. World Economic Outlook. (Sept.) Washington, DC: International Monetary Fund.

Krugman, P. 1994. The myth of Asia's miracle. Foreign Affairs 73:62-78.

Malkiel, B., and J. P. Mei. 1998. Global Bargain Hunting: The Investor's Guide to Profits in Emerging Markets. New York: Simon Schuster.

Mankiw, N. G. 2005. Comment on asset prices and economic growth. Brookings Papers on Economic Activity 1:316-21.

Mobius, M. 1994. The Investor's Guide to Emerging Markets. Columbus, OH: McGraw-Hill.

Modigliani, F., and M. Miller. 1958. The cost of capital, corporation finance, and the theory of investment. American Economic Review 48 (3): 261-97.

Stulz, R. 1999. Globalization, corporate finance and the cost of capital. Journal of Applied Corporate Finance 12 (3): 8-25.

Young, A. 1995. The tyranny of numbers: Confronting the statistical realities of the East Asian growth experience. Quarterly Journal of Economics 110:641-80. 


\section{Comment Takatoshi Ito}

There are good reasons to believe that stock prices will rise in emerging economies with high economic growth rates. High economic growth is usually supported by high corporate earning growth. High corporate earning growth should make stock prices soar.

But, after examining the data of stock returns from emerging market countries, Peter Henry reports that the positive relationship between high economic growth and high stock returns is not confirmed among emerging markets or in a comparison between the emerging market and the United States or even in the comparison of East Asia and Latin America. Then, Henry tries to investigate why the educated guess of the positive association of economic growth and stock returns is not observed in the data.

Is it true that growth theory predicts the positive association? Henry points out that according to a standard Solow model, the positive association may not be obtained. Suppose two economies grow at the same steady state. One economy increases the saving rate, then experiences a temporal increase in growth rate on the way to a new steady state with a higher capital/labor ratio. But when the new steady state is obtained, the growth rate comes back to the original rate (since the growth rate is independent of the saving rate at any steady state), while the return to capital is decreased. However, this comparison, explained by Henry, is not fair. The comparison of the emerging market economies and the United States, or the comparison of low-middle income emerging market and middle-income emerging market economies, should be cast in the convergence story of growth rate. The country with a lower level of income should have higher growth and higher return to capital, while the country with high level of income, near the global steady state, should have a lower growth rate and lower return to capital. The positive association is predicted.

Henry then points out the possibility that the Asian growth may have been expected (at the beginning of the sample period of his study). The stock prices back then may have already discounted the high growth and high returns in the future. Therefore, ex-post returns may not be as high as economic growth. The expected returns were constructed using the IMF World Economic Outlook (WEO) forecasts as expected growth of corporate yields. The table (table 8.2), using data of 1985-2000, shows the following: (a) the expected returns were highest in Asia, followed by Latin America, and last the United States; (b) realized returns were higher than expected returns, especially so in Latin America; (c) realized returns were highest in Latin America, followed by the United States, and last Asia; (d) realized growth was highest in Asia followed by the United States and,

Takatoshi Ito is a professor at the Graduate School of Economics, Tokyo University, and a research associate of the National Bureau of Economic Research. 
equally, Latin America. These facts seem to be quite surprising. Henry interpreted the set of results as the already high expectation of Asian growth in 1985, while Latin American countries experienced high unexpected growth and stock returns. Causality may run from stock prices to growth.

However, WEO projections may be too remote to expected growth of earning yields, although the WEO projections may be good proxies for expected economic growth rate. It can be tested in a long-time series of advanced countries whether stock returns really predict future economic growth.

A grouping of Asia and Latin America may be too crude, in that individual countries have very different results, as shown in table 8.2. The returns also widely fluctuate from year to year; for example, in Argentina, from $-100.5 \%$ in 1982 to $+156.2 \%$ in 1991 . It is important to examine the performance of individual countries as well as the region.

Possible explanations that are not examined in Henry's chapter included the following factors. First, the stock price index of an emerging market economy may not have a representative group of firms. In an emerging market economy, it may be the case that the stock market, that is sometimes heavily regulated with some policy intentions, is represented with unfairly large weights by (former) state-owned companies or traditional resourcerelated companies, while economic growth is mostly realized by activities of (joint venture) companies with foreign direct investment (FDI), and FDI companies may not be listed in the stock market. Second, the emerging market stock returns, especially those of Asian countries, may be actually high for the U.S. based investors, if the returns are measured in the U.S. dollars, since the exchange rates of high economic growth countries tend to appreciate (i.e., the Balassa-Samuelson effect). Third, several emerging market economies started to grow when they implemented various economic reforms and opened their economies to foreign investment. The opening of the economy had impacts on economic growth, through promoting more investment and introducing modern corporate governance. Stock returns will also rise soon after, if not at the same time, as economic reforms, as the stock prices start to reflect future earning growth. Since timing of economic reform is different for different countries, the event study is called for. A study of lining up the timing of economic reform, a jump in economic growth, and a jump in stock prices may reveal an interesting time-series causality of economic growth and stock returns, and provide richer data to Henry's work. 


\section{Comment Etsuro Shioji}

This chapter starts from the observation that, despite higher growth rates, emerging markets are not necessarily characterized by higher stock returns compared to more developed economies. This finding may be at odds with prior expectations of some economists, especially if their intuition comes from the neoclassical growth model (whose main feature is diminishing returns to capital) with no cross country differences in technology. To investigate the source of this contradiction, the authors decompose those realized stock returns into expected and unexpected returns. They find the following two: (a) the average expected returns are no higher in emerging markets than among developed countries, and (b) there is a great deal of heterogeneity among emerging markets. Hence, the objective of the chapter is twofold: to study why the average expected returns are not higher in emerging markets, and to find sources of the differences among those markets. In my view, the latter is the more important (and interesting!) as, given the large diversity within the emerging market group, the group average is not likely to have much economic significance. Results from the regional comparisons are sensitive to the way expected returns are computed, but when they are calculated by the earnings yield (the method that seems to be slightly favored by the authors), Latin America has much higher expected returns than the United States, which in turn has higher expected returns than Asia. The authors propose the following interpretation. At the beginning of the sample period of their analysis (1985), subsequent strong growth of Asia had already been largely anticipated. As a consequence, it was already reflected in its stock prices, not expected returns. By contrast, Latin America's high growth was a consequence of reform efforts by the governments, which were unexpected as of 1985 .

This chapter raises important questions. Perhaps some researchers had sensed a need to explore them in the past, but none (to my knowledge) faced them with the same degree of seriousness as do the authors of the chapter. It is my hope that much work will follow to answer the questions put forth by the authors. My comments are as follows:

\section{Survivorship Bias}

The authors have at least partially responded to my comments regarding this point in the revised version of the chapter, but let me discuss it one more time here, as it can potentially be important. Presumably, the stock returns data are constructed by taking averages of firms existing in the

Etsuro Shioji is a professor in the Graduate School of Economics at Hitotsubashi University. 
market at each point in time (though the authors do not discuss the data construction in much detail). Those firms that disappear in the middle will not be considered in the calculation of the stock indices in subsequent periods. This means that, toward the end of the sample period, "survivors" will be over-represented in the sample. This could introduce an upward bias in the computed average returns: the fact that the average over the sample period was, say, 10 percent does not necessarily mean that one could have earned 10 percent by investing in an average firm at the beginning of the sample. This problem could be particularly serious in crisisridden emerging markets. As the authors point out in the revised version, this problem may not be so consequential to the discussion on the comparison between the United States and emerging markets as a whole, but could be important in the comparison between different emerging markets (which, as I said above, is more interesting in my view). As the authors say, it is not clear in which market the bias is stronger. It may be that, as Latin America has had more crises, the bias is larger there than in Asia. But the depth of the crises should also matter. I hope future work will shed more light on this issue.

\section{Was Asia's High Growth Anticipated in 1985 ?}

Note that Asia in this chapter includes not only the "tigers," but latecomers such as China and India. To test whether we could have predicted Asia's strong growth based on what we knew as of 1985, I run the following Barro-style cross country regression. The left-hand side variable is each country's growth rate of per capita GDP (PPP based) between 1985 and 2000. The explanatory variables are GDP per capita (denoted by $y$ ), ratio of investment to GDP (denoted as $I / Y$ ), ratio of government spending to GDP (denoted as $G / Y$ ), a measure of openness (exports plus imports as ratio to GDP, denoted as Open), all measured as of 1985. I also included dummies for Asia and Latin America (as defined in the same way as in the chapter), denoted Asia and $L A$, respectively. Data source is the Penn World Table, and the sample size was 103 . Here is the result:

$$
\begin{aligned}
& (\text { Growth rate, } 1985-2000)=0.04^{*} y+0.045(I / Y)-0.009(G / Y) \\
& +0.011^{* *} \text { Open }+0.033^{* *} \text { Asia }-0.001 L A-0.043 \quad\left(\mathrm{R}^{2}=0.272\right)
\end{aligned}
$$

In the above, "**, "“**," and " ****" indicate significance at the 10 percent, 5 percent, and 1 percent levels, respectively. Note that the Asia dummy is highly significantly positive, even after controlling for the effects of other variables that might affect the growth rate. Judging from this, it seems difficult to conclude that Asia's high growth was already anticipated in 1985. I also tried including the growth rate between 1965 and 1985 as an additional explanatory variable, but the results were unchanged. Other modifications did not overturn the results, either. 


\section{Degree of Integration into the World Financial Market}

Throughout the chapter, the underlying assumption is that the emerging markets are not fully integrated into the world financial market. If they were, expected returns would be identical everywhere, and different prospects for earnings would be reflected entirely in stock price differentials, not in returns differentials. (Of course, realistically, one would also have to worry about risk premia.) This argument suggests that there is a potentially important determinant of expected returns in each market, not fully discussed in the chapter- degree of integration into the world financial market. Suppose, for the sake of argument, that Asia and Latin America would have the same value of expected returns under autarky, and that this rate would be higher than those in developed countries. Suppose, further, that the Asian market is actually more integrated into the world market. Then the actual expected returns would be lower in Asia. A similar argument could be applied along the time series dimension: a country that experiences a reform that enhances the integration would have lower expected returns in the post reform period (though the reform itself is likely to produce windfall gains in the short run, as discussed by the authors). Hence, historical averages may not be very useful indicators for the current expected returns in such a country. I hope future work will deal with this issue properly.

\section{Expected Returns vs. Stock Prices}

As stated earlier, the authors' explanation for the low expected returns in Asia (despite its fast growth) was that the growth was largely expected from the beginning, and thus was reflected in the levels of stock prices, not returns. If we push this argument further, and assume that any prospect for growth would be reflected in stock prices, we would reach a rather uncomfortable conclusion that there should be no correlation whatsoever between expected growth and expected returns in the world. But this is against our intuition. The relationship between growth and prices/returns is probably a more intricate one, and we need more guidance from growth theory (not the Solow-Swan model, in which expectation plays no role, but the Ramsey-Cass-Koopmans model) to understand what kinds of growth prospects are reflected solely in stock prices, and what kinds affect returns as well. For example, the theory predicts that, if growth is high because of a higher current TFP, the current marginal product of capital would also be higher and that should affect expected returns on financial assets. On the other hand, a higher future TFP leaves the current marginal product unchanged but increases current stock prices. 


\section{Technology Differentials}

As I stated in the beginning, the fact that emerging markets do not necessarily exhibit higher returns may be surprising for students of growth theory, if they assume that the levels of technology are the same across countries. However, recent literature on growth has paid much attention on the differences in the levels of technology "broadly defined." They include the level of financial development (King and Levine 1993), human capital (Lucas 1988, 1990), governmental institutions, public capital, and social capital (Knack and Keefer 1997), among others. By borrowing those ideas from this old literature, I believe this literature on stock market returns will be much more enriched.

\section{Some More Discussions on Institutional Details Would Be Useful}

Many emerging markets have experienced fundamental changes in economic institutions in the past few decades. One might worry if a market today can be reasonably considered the same as the beginning of the sample period. Some discussion on the stability (or instability) of institutional features of each market would be quite useful to the reader.

\section{Other Comments}

Table 8.2 of the chapter, which shows fluctuations in realized returns in each market, is quite informative. The returns show large year-to-year fluctuations. This makes me wonder if the estimation results in the chapter are sensitive to the sample period, especially in which year the sample ends. In the discussion on the effects of reforms in Latin America, it would be interesting if the authors could separately estimate the effects of reforms per se and those of the foreign assistance that was given to the country conditional on implementation of the reforms.

\section{References}

King, R. G., and R. Levine. 1993. Finance and growth: Schumpeter might be right. Quarterly Journal of Economics 108:717-37.

Knack, S., and P. Keefer. 1997. Does social capital have an economic payoff? A cross-country investigation. Quarterly Journal of Economics 112 (4): 1251-88.

Lucas, R. E. 1988. On the mechanics of economic development. Journal of Monetary Economics 22:3-42.

Lucas, R. E. 1990. Why doesn't capital flow from rich to poor countries? American Economic Review, Papers and Proceedings, 92-96. 